\title{
IMPLIKASI SOSIO YURIDIS TUNTUTAN PIDANA TERHADAP DOKTER TERKAIT DUGAAN MALPRAKTIK MEDIK
}

\author{
Oleh \\ Muh Endriyo Susila \\ Fakultas Hukum Universitas Muhamadiyah Yogyakarta \\ Email : endriosusila@gmail.com \\ Dirwan Suryo Soularto \\ Fakultas Kedokteran dan Ilmu Kesehatan Universitas Muhamadiyah Yogyakarta \\ Email: dirwansuryo@yahoo.com
}

\begin{abstract}
Abstrak
Ketiadaaan peraturan yang secara khusus mengatur isu malpraktek medik membuat mimpi buruk menjadi ancaman yang nyata bagi profesi medik di Indonesia, Dokter bisa terjerat dalam tuntutan pidana karena berbagai sebab termasuk dugaan malpraktek medik.Tidak ada yang mempersoalkan tuntutan pidana terhadap dokter dalam kasus aborsi ilegal atau perdagangan organ tubuh, tetapi tuntutan pidana terhadap dokter dalam kasus dugaan malpraktek medik telah menimbulkan kontroversi. Dalam kasus dokter Ayu, penjatuhan sanksi pidana oleh majelis hakim kasasi kepada ketiga terdakwa telah membangkitkan gelombang protes dari kalangan dokter di seluruh Indonesia. Putusan Kasasi dalam kasus dokter Ayu telah memunculkan sikap skeptis dari kalangan profesi medik terhadap hukum dan proses penegakkannya. Aparat penegak hukum terkesan lebih condong pada pasisen daripada dokter dalam merespons kasus dugaan malpraktek medik. Perlindungan terhadap kepentingan pasien lebih diutamakan daripada menghargai itikad baik dokter untuk menolong pasien. Kondisi ini telah menciptakan ketakutan dan kekhawatiran di kalangan dokter akan risiko gugatan/tuntutan hukum. Di satu sisi ketakutan dan kekhawatiran di kalangan dokter mendorong para dokter untuk bekerja lebih berhati-hati, namun disisi lain justru mendorong profesi dokter menerapkan apa yang disebut sebagai defensive medicine yang justru akan merugikan pasien dan masyarakat. Tulisan ini akan mengkaji implikasi tuntutan pidana terhdap dokter pada aspek sosial dan yuridis.
\end{abstract}

Kata Kunci : Malpraktik Medik, Tindak pidana Medik, Tuntutan Pidana. 


\title{
IMPLICATION OF SURIOUS CRIMINAL JURIDIS IMPLICATIONS RELATED TO DOCTOR ALSO MEDICAL MALPRACTICS
}

\author{
Oleh \\ Muh Endriyo Susila \\ Fakultas Hukum Universitas Muhamadiyah Yogyakarta \\ Email : endriosusila@gmail.com
}

Dirwan Suryo Soularto

Fakultas Kedokteran dan Ilmu Kesehatan Universitas Muhamadiyah Yogyakarta

Email: dirwansuryo@yahoo.com

\begin{abstract}
The absence of a regulation that specifically regulates the issue of medical malpractice makes nightmares a real threat to the medical profession in Indonesia, Doctors may be caught in criminal charges for various reasons including medical malpractice allegations. No one questions the criminal charges against doctors in cases of illegal abortion or trafficking organs, but criminal charges against doctors in cases of medical malpractice allegations have caused controversy. In the case of Ayu doctors, the imposition of criminal sanctions by the judges of the cassation to the three defendants has aroused a wave of protests from doctors throughout Indonesia. The Cassation Decision in the case of Ayu's doctor has given rise to skepticism from the medical profession to law and its enforcement process. Law enforcement officers seem more inclined to pasisen than doctors in responding to cases of medical malpractice allegations. The protection of the patient's interests takes precedence over appreciating the doctor's good faith to help the patient. This condition has created fear and anxiety among doctors about the risk of lawsuits / lawsuits. On the one hand fear and anxiety among doctors encourage doctors to work more carefully, but on the other hand it encourages the profession of doctors to apply what is called a defensive medicine that would harm patients and society. This paper will examine the implications of criminal charges against doctors on social and juridical aspects.
\end{abstract}

Keywords: Medical Malpractice, Medical Crime, Criminal Prosecution

\section{A. PENDAhuluan}

Menanggapi maraknya gugatan hukum terhadap dokter terkait kasus malpraktik medik John Healy ${ }^{1}$ berkomentar, 'it is not an easy time to be a doctor'. Pernyataan tersebut barangkali tepat mewakili perasaan kalangan dokter di Indonesia, terutama

1 John Healy, Medical Negligence: Common Law Perspectives, London: Sweet \& Maxwell, 1999 hal.1 paska putusan Mahkamah Agung Nomor: $365 \mathrm{~K} / \mathrm{PID} / 2012$. Majlis hakim pada tingkat kasasi menjatuhkan pidana sepuluh bulan penjara kepada dokter Ayu dan kedua rekannya karena kegagalan operasi sesar yang mengakibatkan meninggalnya pasien, Ny Sisca Makatay, pada tahun 2010 yang lalu. Perkara pidana yang dipopulerkan oleh media masa dengan sebutan 'kasus dokter 
Ayu' tersebut benar-benar fenomenal dan kontroversial. Pemidanaan terhadap tersebut telah membuat kalangan dokter mengalami shocked. Sebagai akibatnya berbagai aksi demonstrasi digelar hampir di seluruh penjuru tanah air. ${ }^{2}$ Puncaknya, atas anjuran Pengurus Besar Ikatan Dokter Indonesia kalangan dokter melakukan aksi mogok nasional pada tanggal 27 November 2013 sebagai bentuk solidaritas terhadap nasib terpidana.

Tidak dipungkiri bahwa tuntutan pidana merupakan mimpi buruk bagi setiap dokter. Dan ketiadaan peraturan hukum yang secara khusus mengatur masalah malpraktik medik di Indonesia telah membuat mimpi buruk itu menjadi ancaman yang nyata. Dokter bisa terjerat dalam tuntutan pidana karena berbagai sebab, termasuk karena dugaan malpraktik medik. Akan tetapi, tuntutan pidana terhadap dokter membawa dampak buruk dalam bidang pelayanan kesehatan, salah satunya adalah praktik defensive medicine.

\section{B. PERMASALAHAN}

Implikasi Sosio-Yuridis Apakah yang timbul akibat adanya tuntutan pidana terhadap[ dokter terkait dugaan malpraktik medik?

\section{PEMBAHASAN}

\section{RUANG LINGKUP TUNTUTAN PIDANA TERHADAP DOKTER}

Sesuai prinsip 'equality before the law' setiap warga negara yang terlibat dalam suatu tindak pidana dapat dituntut secara pidana di muka pengadilan, termasuk dokter. Dokter dapat dipidana apabila terbukti bersalah melakukan suatu perbuatan yang

2 "Ini Selengkapnya Pertimbangan Hakim Kasasi Kasus Dokter Ayu", diunduh pada tanggal 13 Oktober 2014 dari http://www.gresnews.com/berita/hukum/17602811-inipertimbang-hakim-kasasi-kasus-dr-ayu. berdasarkan peraturan perundang-undangan yang berlaku dinyatakan sebagai tindak pidana.

1. Tuntutan Pidana Berdasarkan KUHP

Tuntutan pidana terhadap dokter dapat dilakukan dalam hal yang bersangkutan melakukan tindak pidana sebagaimana diatur dalam KUHP sebagai berikut:

a) Menerbitkan surat keterangan kesehatan palsu

Pasal 267 melarang dokter menerbitkan surat keterangan kesehatan palsu mengenai ada atau tidak adanya penyakit pada diri seoang pasien. Pelanggaran terhadap ketentuan ini diancam dengan pidana penjara paling lama empat tahun. Jika surat keterangan tersebut dimaksudkan untuk memasukkan pasien ke dalam Rumah Sakit Jiwa (RSJ) atau dimaksudkan agar seorang pasien di RSJ tetap berada di sana, perbuatan tersebut diancam dengan pidana penjara paling lama delapan tahun dan enam bulan.

b) Melakukan perbuatan asusila terhadap pasien

Pasal 294 (2) melarang setiap orang melakukan perbuatan asusila terhadap orang-orang yang ada dalam perawatannya. Pelanggaran terhadap ketentuan ini diancam dengan pidana penjara paling lama tujuh tahun. Ketentuan ini juga berlaku antara dokter dan pasien.

c) Membuka informasi yang bersifat rahasia

Pasal 322 melarang setiap orang untuk membuka setiap informasi yang bersifat rahasia dan wajib dijaga kerahasiaannya. Pelanggaran terhadap ketentuan ini diancam dengan pidana penjara paling lama sembilan bulan atau denda paling banyak sembilan ribu rupiah. Ketentuan ini berlaku untuk dokter yang membuka rahasia pasien.

d) Melakukan Euthanasia

Pasal 344 KUHP melarang dokter 
memenuhi permintaan pasien untuk mengakhiri hidup si pasien tersebut (mercy killing/euthanasia). Pelanggaran terhadap ketentuan ini diancam dengan pidana penjara paling lama dua belas tahun.

e) Melakukan aborsi

Pasal 348 (1) melarang setiap orang melakukan tindakan pengguguran kandungan secara sengaja (aborsi). Pelanggaran terhadap ketentuan ini diancam dengan pidana penjara paling lama lima tahun enam bulan. Jika pengguguran kandungan itu telah menyebabkan matinya ibu hamil, berdasarkan ketentuan Pasal 348 ayat 2 perbuatan tersebut diancam dengan pidana penjara paling lama lima belas tahun. Jika pelaku perbuatan adalah dokter, bidan, dan apoteker maka berdasarkan ketentuan pasal 349 hukumannya diperberat sepertiga dan ditambah dengan pencabutan izin praktik.

f) Ketentuan Pasal 351 tentang penganiayaan.

Menurut ketentuan tersebut, setiap orang yang secara sengaja melakukan penganiayaan diancam dengan pidana penjara paling lama dua tahun delapan bulan. Jika penganiayaan tersebut telah mengakibatkan luka-luka perbuatan tersebut diancam dengan pindana penjara paling lama lima tahun. Ketentuan ini dapat diterapkan pada dokter yang melakukan tindakan medis tanpa persetujuan si pasien, karena perbuatan demikian disamakan dengan penganiayaan.

g) Pasal 359 tentang kelalaian yang menyebabkan kematian.

Menurut ketentuan tersebut, setiap orang yang karena kelalaiannya telah mengakibatkan orang lain meninggal dunia diancam dengan pidana penjara paling lama lima tahun atau pidana kurungan paling lama satu tahun. Ketentuan ini dapat diterapkan kepada dokter yang karena kelalaiannya mengakibatkan pasien meninggal dunia. h) Pasal 360 tentang kelalaian yang menyebabkan timbulnya luka-luka.

Menurut ketentuan tersebut, setiap orang yang karena kelaiannya menyebabkan orang lain mengalami luka-luka serius diancam dengan pidana penjara paling lama lima tahun atau pidana kurungan paling lama satu tahun. Ketentan ini dapat diterapkan pada dokter yang karena kelalaiannya telah menyebabkan pasiennya menderita lukaluka serius.

Terkait dengan ketentuan pasal 359 dan 360 tersebut, hakim berdasarkan ketentuan Pasal 361 dapat memperberat hukuman jika perbuatan tersebut dilakukan dalam rangka menjalankan pekerjaan. Jadi status sebagai dokter menurut ketentuan Pasal 361 berlaku sebagai alasan pemberat hukuman (aggravating factor).

2. Tuntutan Pidana Berdasarkan Undangundang Nomor 29 Tahun 2004 Tentang Praktik Kedokteran

Undang-undang Nomor 29 Tahun 2004 tentang Praktik Kedokteran (UU Praktik Kedokteran) telah menetapkan beberapa macam perbuatan sebagai tindak pidana. Dalam undang-undang ini ketentuan pidana diatur di dalam Pasal 75 hingga Pasal 80. Ada tiga pihak yang dapat menjadi pelaku tindak pidana berdasarkan UU Praktik Kedokteran, yaitu dokter/dokter gigi, pemilik sarana pelayanan kesehatan dan orang lain yang bukan dokter/dokter gigi. Berikut ini adalah bentuk-bentuk tindak pidana yang diatur dalam UU Praktik Kedokteran:

1) Tidak Memiliki Surat Tanda Registrasi (STR)

Menurut ketentuan pasal 75 UU Praktik Kedokteran, melakukan praktik kedokteran tanpa memiliki STR diancam dengan pidana paling lama tiga tahun atau denda paling banyak seratus juta rupiah.

2) Tidak Memiliki Surat Ijin Praktik (SIP) 
Menurut ketentuan pasal 76 UU Praktik Kedokteran, melakukan praktik kedokteran tanpa memiliki SIP diancam dengan pidana penjara paling lama tiga tahun atau denda paling banyak seratus juta rupiah.

3) Tidak Memasang Papan Nama Praktik.

Menurut ketentuan pasal 79 (a) UU Praktik Kedokteran tidak memasang papan nama praktik diancam dengan pidana kurungan paling lama satu tahun atau dengan paling banyak lima puluh juta rupiah.

4) Tidak Membuat Rekam Medik

Menurut ketentuan pasal 79 (b) UU Praktik Kedokteran tidak membuat rekam medik diancam dengan pidana kurungan paling lama satu tahun atau denda paling banyak lima puluh juta rupiah.

5) Tidak mematuhi standar pelayanan

Menurut ketentuan pasal 79 (c) UU Praktik Kedokteran tidak mematuhi standar pelayanan sebagaimana dimaksud dalam pasal 51 (a) diancam dengan pidana kurungan paling lama satu tahun atau denda paling banyak lima puluh juta rupiah.

6) Tidak merujuk pada dokter lain yang lebih ahli

Menurut ketentuan pasal 79 (c) UU Praktik Kedokteran tidak merujuk pasien ke dokter lain yang lebih ahli dalam hal tidak mampu menangani sakit yang diderita pasien sebagaimana dimaksud dalam pasal 51(b) diancam dengan pidana kurungan paling lama satu tahun atau denda paling banyak lima puluh juta rupiah.

7) Tidak memberikan pertolongan darurat

Menurut ketentuan pasal 79 (c) UU Praktik Kedokteran tidak memberikan pertolongan darurat sebagaimana dimaksud dalam pasal 51 (c) diancam dengan pidana kurungan paling lama satu tahun atau denda paling banyak lima puluh juta rupiah.

8) Membuka rahasia pasien

Menurut ketentuan pasal 79 (c) UU Praktik Kedokteran membuka rahasia pasien sebagaimana dimaksud dalam pasal 51 (d) diancam dengan pidana kurungan paling lama satu tahun atau denda paling banyak lima puluh juta rupiah.

9) Tidak meningkatkan pengetahuan dan ketrampilan kedokteran.

Menurut ketentuan pasal 79 (c) UU Praktik Kedokteran tidak meningkatkan pengetahuan dan ketrampilan kedokteran sebagaimana dimaksud dalam pasal 51 (e) diancam dengan pidana kurungan paling lama satu tahun atau denda paling banyak lima puluh juta rupiah.

Memperhatikan beberapa ketentuan pidana di atas terlihat dengan jelas bahwa UU Praktik Kedokteran telah mengkriminalisasi beberapa kesalahan yang bersifat administratif seperti tidak memiliki STR/SIP, tidak membuat rekam medik, dan tidak memasang papan nama praktik. Kriminalisasi terhadap berbagai kesalahan administratif pada satu sisi dapat dilihat sebagai wujud komitmen yang kuat dari para pembuat undang-undang untuk memberikan perlindungan maksimum kepada masyarakat terhadap potensi kerugian akibat praktik kedokeran yang dilakukan oleh pihak-pihak yang tidak berkompeten. Namun pada sisi yang lain, penggunaan sanksi pidana dalam bentuk penjara maupun kurungan terhadap kesalahan yang bersifat administratif dalam hal-hal tertentu nampak berlebihan atau tidak proporsional. Oleh karenanya ketentuan pidana semacam ini telah menjadi objek judicial review di mahkamah konstitusi dan telah diamandemen pada tahun 2007.

Uji materi (judicial review) diajukan oleh Anny Isfandyarie, seorang dokter spesialis anastesi. ${ }^{3}$ Berdasarkan putusan Mahkamah Konstitusi pada tanggal 19 juni

3 Putusan Mahkamah Konstitusi Nomor 4/PUU-V/1997 tentang Permohonan Pengujian Undang-undang Nomor 29 Tahun 2004 Tentang Praktik Kedokteran, diunduh pada tanggal 13 Oktober 2014 dari http://hukumpidana. bphn.go.id/wp-content/uploads/2012/11/Putusan-MKNo.-4_PUU_V_2007.pdf 
2007, UU Praktik Kedokteran sepanjang menyangkut pidana penjara dan kurungan yang diancamkan terhadap tindak pidanatindak pidana yang diatur dalam Pasalpasal 75, 76, dan 79 (c) telah dihapuskan. Penghapusan ancaman pidana penjara dan kurungan tersebut tidak berarti tindak pidana yang bersangkutan telah dihapuskan (dekriminalisasi). Tindak pidana-tindak pidana tersebut tetap berlaku hanya saja tidak lagi diancam dengan sanksi yang bersaifat merampas kemerdekaan, melainkan diancam dengan sanksi denda.

3. Tuntutan Pidana Berdasarkan Undangundang Nomor 36 Tahun 2009 Tentang Kesehatan

Ada beberapa jenis tindak pidana yang diatur dalam UU Kesehatan yang mungkin bisa menjerat tenaga medik yaitu:

a) Terlibat dalam perdagangan organ atau jaringan tubuh sebagaimana diatur dalam pasal 192

Pasal 192 UU Kesehatan menentukan bahwa memperdagangkan organ atau jaringan tubuh diancam dengan pidana penjara paling lama sepuluh tahun atau denda paling banyak satu miliar rupiah.

b) Melakukan operasi bedah plastik unutuk tujuan memalsukan identitas seseorang sebagaimana diatur dalam pasal 193

Pasal 193 UU Kesehatan menentukan bahwa melakukan operasi bedah plastik unutuk tujuan memalsukan identitas seseorang diancam dengan pidana penjara paling lama sepuluh tahun atau denda paling banyak satu miliar rupiah.

c) Melakukan pengguguran kandungan secara tidak sah sebagaimana diatur dalam pasal 194

Pasal 194 UU Kesehatan menentukan bahwa melakukan pengguguran kandungan secara tidak sah diancam dengan pidana penjara paling lama sepuluh tahun atau denda paling banyak satu miliar rupiah. d) Memperjualbelikan darah sebagaimana diatur dalam pasal 195

Pasal 195 UU Kesehatan menentukan bahwa memperjualbelikan darah diancam dengan pidana penjara paling lama lima tahun atau denda paling banyak lima ratus juta rupiah.

\section{BERBAGAI ISU TERKAIT TUNTUTAN PIDANA TERHADAP DOKTER DI INDONESIA}

Dalam menjalankan aksi protes terkait pemidanaan terhadap dokter Ayu dan kedua rekannya, kalangan dokter menuntut dihentikannya kriminalisasi terhadap dokter. ${ }^{4}$ Mereka beranggapan bahwa memidana dokter disebabkan oleh karena kegagalannya dalam melaksanakan suatu tindakan medik adalah sebuah ketidakadilan. Tuntutan pidana tidak boleh dibuat sematamata berdasarkan adverse outcome, yakni hasil pengobatan yang tidak sesuai harapan. Tindakan medik menurut sifatnya memang tidak dapat menjanjikan hasil yang pasti. Meskipun hasilnya tidak sesuai yang diharapkan, sepanjang tindakan medik telah dilakukan sesuai standar, seharusnya dokter memperoleh perlindungan hukum.

Jargon 'stop kriminalisasi terhadap dokter' yang diusung kalangan profesi kedokteran terutama saat melakukan aksi unjuk rasa pada akhir 2013 yang lalu mendapatkan tanggapan berbeda-beda dari masyarakat. Ada yang dapat memakluminya, namun ada pula yang kurang bisa menerimanya. Bahkan, ada yang mengkritisi tuntutan tersebut sebagai sebuah bentuk tuntutan untuk memperoleh perlakuan khusus secara hukum (legal privilege).

Sebagaimana anggota masyarakat lainnya, dokter tidak memiliki kekebalan hukum (legal immunity). Ketika seorang dokter melakukan suatu perbuatan yang

"Stop Kriminalisasi Dokter", diunduh pada tangga 13 Oktober 2014 dari http://www.esamarinda. com/2013/11/26/stop-kriminalisasi-dokter/8785/ 
berdasarkan ketentuan hukum yang berlaku merupakan tindak pidana, maka yang bersangkutan dapat ditunutut secara pidana. Logika semacam ini sebenarnya telah dipahami dengan baik oleh kalangan profesi kedokteran. Pada kenyataannya, tidak ada yang mempersoalkan tuntutan pidana terhadap dokter yang melakukan tindakan kriminal seperti aborsi ilegal atau jual-beli organ tubuh. Akan tetapi, tuntutan pidana terhadap dokter terkait dengan peristiwa yang secara sosiologis dikonstrusikan sebagai malpraktik medik telah menimbulkan kontroversi serta konsekuensi negatif lainnya.

Sebagaimana dapat dilihat pada kasus dokter Ayu, selain menimbulkan kontroversi di tengah-tengah masyarakat, penjatuhan sanksi pidana oleh Mahkamah Agung telah membangkitkan gelombang protes kalangan dokter dari seluruh penjuru Indonesia. Puncak dari aksi protes tersebut adalah dilakukannya aksi mogok nasional pada tanggal 27 November 2013 di berbagai rumah sakit di Indonesia. Lebih mengejutkan lagi, aksi mogok tersebut ternyata mendapatkan dukungan dari Menteri Kesehatan kala itu. ${ }^{5}$ Dari sudut pandang dokter, aksi mogok tersebut dapat dibenarkan sebagai sebuah upaya menyampaikan aspirasi dan sebagai upaya perlawanan atas ketidakadilan yang terjadi. Namun dari perspektif yang lain, aksi mogok tersebut tidak dapat diterima karena dianggap telah mengganggu pelayanan publik. Jadi, selain kontroversi tentang pemidanaan terhadap dokter Ayu, muncul pula kontroversi baru di tengahtengah masyarakat terkait pantas tidaknya aksi mogok dilakukan oleh kalangan dokter. ${ }^{6}$

5 "Kemenkes Dukung Aksi Mogok Dokter Se-Indonesia", diunduh pada tanggal 13 Oktober 2014 dari http:// nasional.news.viva.co.id/news/read/461728-kemenkesdukung-aksi-mogok-dokter-se-indonesia. "Aksi Mogok Dokter Bertentangan dengan Kemanusiaan", diunduh pada tanggal 13 Oktober 2014 dari http://www.tribunnews.com/nasional/2013/11/26/ aksi-mogok-dokter-bertentangan-dengan-kemanusiaan.
Dalam batas-batas tertentu sepertinya tuntutan pidana terhadap dokter lebih banyak menciptakan masalah dari pada memberi solusi. Jika pemidanaan terhadap dokter Ayu dan kedua rekannya dimaksudkan untuk melindungi masyarakat resiko/bahaya malpraktik medik, pada kenyataannya penjatuhan sanksi pidana tersebut justeru telah menghadirkan bahaya lain kepada masyarakat salah satunya adalah penerapan pola defensive medicine. Jika demikian yang terjadi, maka penggunaan sarana penal dalam perkara malpraktik medik patut dipertanyakan.

Sebagaimana telah dipahami bahwa dalam mengatasi persoalan-persoalan sosial, sarana penal seharusnya digunakan sebagai upaya terakhir (last resort). Hukum pidana disifati sebagai ultimum remidium sehingga penggunaan sarana penal mestinya ditempatkan pada prioritas terakhir. Penggunaan sarana penal pada peristiwa yang secara sosial dikonstruksikan sebagai malpraktik medik nampaknya kurang proporsional mengingat ada sarana lain yang lebih sesuai yakni mekanisme pertanggungjawaban perdata (civil liability). Umumnya pihak pasien yang dirugikan lebih suka menerima ganti kerugian daripada mengirim dokter yang telah berusaha menolongnya ke penjara. Bahkan dalam beberapa kasus, pasien yang dirugikan hanya menuntut penjelasan dari pihak rumah sakit tentang apa yang terjadi, ada pula yang sekedar menuntut permohonan maaf. Sebagai bahan perbandingan, di berbagai negara maju penggunaan sarana penal pada kasus malpraktik medik sangat jarang dilakukan. Meskipun malpraktik medik menimbulkan akibat kematian pasien, dalam banyak kasus penyelesaiannya dilakukan secara perdata.

\section{IMPLIKASI SOSIO-YURIDIS TUNTUTAN PIDANA TERHADAP DOKTER}


Tuntutan pidana terhadap dokter dalam kasus dugaan malpraktik medik memang dimungkinkan tetapi tidak setiap kasus dugaan malpraktik medik memerlukan sarana penal. Penggunaan sarana penal pada kasus dugaan malpraktik medik memang sebaiknya dibatasi. Penggunaan sarana penal secara berlebihan justru dapat bersifat kontra produktif, manfaat yang diperoleh tidak seimbang dengan biaya sosial (social cost) yang timbul. Kasus dokter Ayu mestinya memberikan pelajaran berharga bagi aparat penegak hukum dan masyarakat Indonesia. Penegakkan hukum tidak selalu paralel dengan tegaknya keadilan. Penegakkan hukum yang dilakukan dengan pendekatan normatif semata-mata kadang kala justeru menciptakan ketidakadilan.

Dalam praktik di negara-negara maju seperti di Inggris dan Australia, tuntutan pidana terhadap dokter terkait dugaan malpraktik dibatasi pada kasus-kasus tertentu yang dikualifikasikan sebagai 'criminal negligence'. Dimensi kriminalitas dalam konteks criminal negligence lebih didasarkan pada aspek kesalahan (mens rea) dokter, bukan hanya melihat faktor akibat dari tindakan yang dilakukan oleh dokter tersebut. Tuntutan pidana dapat dilakukan pada kasus malpraktik medik (medical malpractice/medical negligence) ${ }^{7}$ apabila derajat kesalahan dokter masuk kategori kelalaian berat (gross negligence). Penentuan apakah derajat kesalahan masuk kualifikasi kelalaian berat atau kelalaian ringan dilakukan oleh hakim. Dalam kasus $R v$ Adamoko House of Lords menyatakan, "negligence is gross when it is so bad that it should be criminal".

Lain di negara maju, lain pula di negara Indonesia. Di Indonesia dokter yang terlibat

7 Di negara Inggris dan Australia serta negara-negara Common Law lainnya istilah medical negligence lebih sering dipakai dibandingkan istilah medical malpractice).

8 Emily Jackson, Medical Law: Text, Cases, and

Materials, Edisi ke 2, Newyork: Oxford University Press, 2010, hal. 146 dalam perbuatan yang secara sosiologis dikonstruksikan sebagai malpraktik medik begitu mudah dihadapkan pada tuntutan pidana. Dimensi kriminalitas dari kasus malpraktik medik lebih sering didasarkan pada akibat dari malpraktik medik itu sendiri. Apabila pasien mengalami luka berat, lebih-lebih jika meninggal dunia umumnya pihak keluarga dan masyarakat luas mengasumsikan peristiwa tersebut sebagai peristiwa pidana. Sebagai konsekswensinya dokter yang telah menyebabkan si pasien menderita luka atau meninggal dunia layak dituntut secara pidana. Bahwa tindakan medik yang dilakukan oleh dokter berawal dari niat baik untuk menolong pasien, dan akibat negatif berupa luka atau kematian itu tidak hanya disesali oleh si pasien atau keluarganya tetapi juga disesali oleh dokter yang bersangkutan serta pihak menajemen rumah sakit seolah tidak dipertimbangkan.

Cara pandang aparat penegak hukum di Indonesia tidak jauh berbeda dengan masyarakat pada umumnya. Sepanjang dapat ditemukan unsur kelalaian, asalkan ada akibat berupa luka atau kematian pasien dengan gampang peristiwa tersebut dikonstruksikan sebagai tindak pidana. Pasal 359 dan 360 KUHP menjadi andalan aparat untuk menjerat dokter yang terlibat. Memang benar kedua ketentuan tersebut secara normatif dapat digunakan untuk menjerat dokter yang karena kelalaiannya menyebabkan pasien menderita luka-luka atau meninggal dunia. Tapi seringkali unsur kelalaian ditafsirkan secara tidak tepat dan pembuktian hubungan kausal antara unsur kelalaian serta akibatnya kadang kala keliru. Pada kasus dokter Ayu misalnya, majlis hakim kasasi menetapkan unsur kelalaian dari terpidana terletak antara lain pada faktor tidak diberikannya penjelasan yang memadai khususnya tentang resiko kematian yang mungkin terjadi akibat dilakukan tindakan operasi sectio cessaria. Dengan demikian dapat dikatakan bahwa ada cacat hukum 
dalam pemberian persetujuan (informed consent) dari pihak keluarga pasien. Selain itu majlis hakim juga menggunakan logika yang keliru dalam menegakkan prinsip kausalitas. Bahwa melakukan tindakan medik apalagi yang beresiko tinggi tanpa persetujuan pasien atau keluarganya itu merupakan sebuah kesalahan/kelalaian itu memang betul, tapi bukan kelalaian semacam itu yang harus diasosiasikan dengan kematian pasien. Andai pun persetujuan operasi telah diberikan sebelumnya, resiko kematian tetap saja tidak dapat dihindari. Demikian pula halnya, jika operasi tidak dilakukan karena tidak ada persetujuan dari pihak keluarga akibatnya tetap sama, pasien akan meninggal dunia. Selain itu majlis hakim juga mempersalahkan terpidana yang karena kelalaiannya telah menyebabkan terjadinya emboli. Adalah benar bahwa secara medis diyakini penyebab kematian pasien adalah karena terjadinya emboli. Tetapi mempertanggungjawabkan dokter atas terjadinya emboli tidaklah adil sebab emboli adalah faktor resiko yang sama sekali tidak dapat diduga sebelumnya (unforeseeable).

Selain itu, tuntutan pidana terhadap dokter pada kasus dugaan malpraktik medik terrnyata membawa berbagai implikasi negatif baik secara sosial maupun yuridis. Berdasarkan hasil penelitian yang pernah dilakukan ditemukan sekurang-kurangnya lima dampak negatif tuntutan pidana terhadap dokter terkait dugaan malpraktik medik yaitu:

1) Membuka peluang pemerasan terhadap dokter oleh oknum pasien dan atau pengacaranya.

Tuntutan pidana membuka celah politiking bagi kalangan pengacara dalam mengangani sengketa medik. Ancaman tuntutan pidana dapat dimanfaatkan oleh oknum pengacara untuk mengintimidasi dokter dan meningkatkan nilai tawar terkait besaran ganti kerugian yang diajukan'. Dokter yang ketakutan bila diperkarakan secara pidana cenderung akan mengikuti kemauan pihak pengacara, dan situasi semacam ini membuat dokter rentan menjadi korban pemerasan.

2) Membuka peluang pemerasan terhadap dokter oleh oknum aparat

Tuntutan pidana juga membuka celah bagi oknum aparat penegak hukum untuk melakukan eksploitasi terhadap dokter yang tersangkut perkara malpraktik medik. Di tingkat penyidikan eksploitasi dilakukan dengan modus penyalahgunaan wewenang oleh oknum penyidik. Penyalahgunaan wewenang dapat dilakukan dalam dua skenario, pertama terkait penetapan status tersangka dan kedua terkait penahanan. Dokter yang dijadikan sebagai tersangka, apalagi jika diikuti dengan penahanan pasti akan mengalami shocked berat, dan kemungkinan besar akan meminta pengacaranya untuk menegosiasikan pelepasan dari status tersangka tersebut atau pelepasan dari tahanan. Negosiasi tersebut tidak bisa lepas dari pembayaran sejumlah uang kepada oknum aparat terkait.

3) Membuka celah praktik defensive medicine oleh kalangan dokter

Bagi sebagian dokter, sengketa medik barangkali masih merupakan sesuatu yang tidak masuk akal. Bagaimana mungkin iktikad baik untuk memberi pertolongan pada pasien justeru membuat dokter tersangkut perkara hukum di pengadilan. Tuntutan hukum terhadap dokter lebih-lebih tuntutan pidana dapat menstimulasi kalangan dokter untuk mempraktikkan pola defensive medicine dimana mereka lebih konsen melakukan pengamanan diri dari pada menerapkan

9 Disimpulkan dari hasil wawancara dengan M. Luthfie Hakim, konsultan hukum rumah sakit, pada tanggal 30 August 2014. M. Luthfie Hakim menggunakan istilah 'kapitalisasi' untuk menyebut upaya pihak-pihak tertentu memanfaatkan kejadian buruk (adverse event) yang dialami oleh pihak pasien sebagai sarana untuk menegosiasikan ganti rugi. 
pelayanan medik terbaik untik pasiennya. Paska pemidanaan terhadap dokter Ayu sebagian dokter diyakini telah benar-benar menerapkan pola defensive medicine tersebut. Praktik defensive medicine akan membebani masyarakat dengan biaya pengobatan yang semakin mahal dan berbagai resiko lainnya.

4) Menimbulkan public distrust terhadap pelayanan kedokteran

Dalam batas-batas tertentu tuntutan pidana juga dapat menciptakan public distrust terhadap pelayanan kedokteran. Kasus dugaan malpraktik medik khususnya yang diproses secara pidana merupakan obyek pemberitaan yang seksi bagi media masa. Pemberitaan yang bersifat masif oleh media masa tentang kasus dugaan malpraktik medik dapat menciptakan ketakutan atau kekhawatiran masyarakat. Masyarakat bisa saja menjadi khawatir kalau-kalau mereka akan menjadi korban malpraktik berikutnya. Anggota masyarakat yang ketakutan bisa saja meninggalkan pengobatan beradasarkan ilmu kedokteran dan beralih ke pengobatan alternatif atau pengobatan tradisional. Akan tetapi mereka juga sadar bahwa pengobatan alternatif sebenarnya juga bukan tanpa resiko. Situasi demikian dapat mengurangi akses masyarakat untuk mendapatkan kesehatan. Lebih dari itu, tuntutan pidana juga seolah memaksa dokter untuk berkonfrontasi dengan pihak pasien. Meskipun dalam sidang pengadilan posisi pasien diwakili oleh negara, tetap saja suasana konfrontatif tersebut tidak dapat dihilangkan. Situasi demikian sangat tidak kondusif bagi terciptanya hubungan yang harmonis antara dokter dan pasien, padahal hubungan demikian sangat dibutuhkan demi keberhasilan terapi. Dapat dikatakan bahwa keadaan demikian dapat mengurangi kualitas komunikasi antara dokter dan pasien dan hal itu berimplikasi pada menurunnya kualitas pelayanan medik

5) Menimbulkan kerancuan terkait konsep malpraktik medik

Tuntutan pidana terhadap dokter terkait dugaan malpraktik medik dalam batasbatas tertentu juga dapat menimbulkan kerancuan pemahaman tentang konsep malpraktik medik. Sebagaimana diketahui istilah malpraktik medik tidak ditemukan dalam peraturan perundang-undangan dan tidak dipergunakan dalam proses beracara. Istilah malpraktik medik di Indonesia lebih merupakan istilah sosiologis (sociological term) dan bukan istilah yuridis (legal term). Karena tidak ada peraturan perundangundangan yang secara khusus mengatur masalah malpraktik medik, maka peristiwa yang dipersepsi sebagai malpraktik medik ditafsirkan berdasarkan peraturan perundang-undangan yang ada. Posibilitas untuk menuntut dokter secara pidana dan didukung oleh fakta bahwa banyak kasus dugaan malpraktik medik yang diproses secara pidana telah membuat masyarakat pada umumnya mempersepsi malpraktik medik sebagai peristiwa pidana. ${ }^{10}$

\section{KESIMPULAN}

Dari berbagai diskusi sebelumnya dapat disimpulkan bahwa penggunaan sarana penal dalam kasus dugaan malpraktik medik memang dimungkinkan tetapi harus dibatasi. Penggunaan sarana penal secara berlebihan justru bisa bersifat kontra produktif bagi upaya mewujudkan keadilan dalam lapangan pelayanan kesehatan. Tuntutan pidana terhadap dokter dalam kasus dugaan malpraktik medik di Indonesia sejauh ini ternyata membawa berbagai implikasi negatif baik secara sosial maupun yuridis. Tuntutan pidana membuka celah penyelewengan hukum dan berbagai

10 Muh Endriyo Susila dan Puteri Nemie, "The Viability of Applying ADR Method for Resolving Medical Malpractice Disputes in Indonesia", makalah dipresentasikan dalam forum the $4^{\text {th }}$ International Conference on Law and Society ( $4^{\text {th }}$ ICLAS) yang diselenggarakan pada tanggal 10-11 May $2015 \mathrm{di}$ UNISZA Terengganu Malaysia. 
implikasi negatif lainnya. Praktik yang berlaku selama ini menempatkan dokter pada posisi rentan. Posisi rentan tersebut dapat menstimulasi kalangan dokter untuk menerapkan pola defensive medicine dalam rangka mengantisipasi resiko gugatan/ tuntutan hukum. Praktik defensive medicine dalam arti yang negatif mestinya harus dihindari karena akan merugikan pasien serta masyarakat luas. Praktik defensive medicine dapat dicegah atau setidak-tidaknya dikurangi apabila sistem penanganan kasus dugaan malpraktik medik memberikan perlindungan yang memadai terhadap dokter, khususnya dari tuntutan pidana yang sebenarnya tidak perlu (unnecessary criminal prosecution).

\section{DAFTAR PUSTAKA}

- Kitab Undang-undang Hukum Pidana (KUHP)

- Kitab Undang-undang Hukum Perdata (KUHPer)

- Undang-undang Nomor 29 Tahun 2004 Tentang Praktek Kedokteran

- Undang-undang Nomor 36 Tahun 2009 Tentang Kesehatan

- Putusan Mahkamah Konstitusi Nomor 4/PUU-V/1997 tentang Permohonan Pengujian Undang-undang Nomor 29 Tahun 2004 Tentang Praktik Kedokteran, diunduh pada tanggal 13 Oktober 2014 dari http://hukumpidana. bphn.go.id/wp-content/uploads/2012/11/ Putusan-MK-No.-4_PUU_V_2007.pdf

- Emily Jackson, Medical Law: Text, Cases, and Materials, Edisi ke 2, New York: Oxford University Press, 2010.

- Sofwan Dahlan, Hukum Kesehatan: Rambu-rambu bagi Profesi Dokter: Edisi 3, (Semarang: Badan Penerbit Universitas Diponegoro, 2002).

- John Healy, Medical Negligence: Common
Law Perspectives, London: Sweet \& Maxwell, 1999.

- Muh Endriyo Susila dan Puteri Nemie, "The Viability of Applying ADR Method for Resolving Medical Malpractice Disputes in Indonesia", makalah dipresentasikan dalam forum the $4^{\text {th }}$ International Conference on Law and Society (4th ICLAS) yang diselenggarakan pada tanggal 10-11 May 2015 di UNISZA Terengganu Malaysia.

"Ini Selengkapnya Pertimbangan Hakim Kasasi Kasus Dokter Аyu", diunduh dari http://www.gresnews.com/berita/ hukum/17602811-ini-pertimbang-hakimkasasi-kasus-dr-ayu. Tanggal 13 October 2014.

"Stop Kriminalisasi Dokter", diunduh dari http://www.esamarinda.com/2013/11/26/ stop-kriminalisasi-dokter/8785/ tanggal 13 Oktober 2014.

"Kemenkes Dukung Aksi Mogok Dokter SeIndonesia", diunduh dari http://neasional. news.viva.co.id/news/read/461728-kemenkesdukung-aksi-mogok-dokter-se-indonesia, tanggal 13 Oktober 2014.

"Aksi Mogok Dokter Bertentangan dengan Kemanusiaan", diunduh dari http://www. tribunnews.com/nasional/2013/11/26/ aksi-mogok-dokter-bertentangan-dengankemanusiaan, tanggal 13 Oktober 2014. 